\title{
KAJIAN DAMPAK PERUBAHAN KEBIJAKAN PENATAUSAHAAN HASIL HUTAN TERHADAP SUPLAI BAHAN BAKU INDUSTRI KAYU DI KALIMANTAN TIMUR
}

(Review Of The Impact Of The Forestry Ministerial Decree Changes On The Supply Of Forest

Timber Industry In East Kalimantan)

$\mathrm{Oleh} / \mathrm{By}$ :

Catur Budi Wiati dan/and Karmilasanti

Balai Besar Penelitian Dipterokarpa, Samarinda

\begin{abstract}
The implementation of Forestry Ministerial Decree No P.55/Menhut-II/2006 is intended to shorten the bureaucratic path to save time and costs associated with it. However, companies in East Kalimantan have difficulty to implement the decree not only because of unprepared human resources for the prompt issuance of required documents but also because ideal field conditions are hard to meet. On the otherhand logs originating from East Kalimantan, especially dipterocarp are important for Indonesian wood industries because around $50 \%$ of the total log supply are from East Kalimantan. This paper discusses problem and impact of the implementation of the Forestry Ministerial decree No. P.55/Menhut-II/2006 to wood potential from natural forest especially dipterocarp in East Kalimantan. The study was conducted from May-December 2007. The result revealed that effective and efficient implementation of the decree brought impact on increasing of log supply locally and nationally.
\end{abstract}

Keywords : Forestry Ministerial Decree No.P.55/Menhut-II/2006, wood trade, effective, efficient

\begin{abstract}
ABSTRAK
Pelaksanaan Permenhut No.P.55/Menhut-II/2006 dimaksudkan untuk memperpendek jalur birokrasi untuk menghemat waktu dan biaya yang dapat berdampak pada biaya pengurusan yang tinggi (high cost economy). Tetapi ketidaksiapan sumberdaya manusia sebagai penerbit dan kebingungan penerapan di lapangan akibat kondisi alam yang tidak ideal menjadi alasan sebagian besar perusahaan di Kalimantan Timur mengalam kesulitan untuk melaksanakan Permenhut No.P.55/Menhut-II/2006 di lapangan. Disisi lain kayu bulat asal hutan alam dari Kalimantan Timur, khususnya jenis dipterokarpa, memegang peranan cukup penting bagi industri pengolahan kayu di Indonesia. Karena sekitar 50\% dari total produksi kayu bulat Indonesia yang dipergunakan untuk bahan baku industri berasal dari Kalimantan Timur. Tulisan ini dimaksudkan untuk menjelaskan hasil penelitian tentang pelaksanaan Permenhut No.P.55/Menhut-II/2006 di Kalimantan Timur,
\end{abstract}


permasalahan yang dihadapi dan dampaknya bagi potensi kayu dari hutan alam, khususnya jenis dipterokarpa, di Kalimantan Timur. Penelitian yang dilakukan sekitar bulan Mei - Desember 2007 ini mendapatkan hasil bahwa pelaksanaan permenhut No.P.55/Menhut-II/2006 yang efektif dan efesien berdampak terhadap peningkatan produksi kayu bulat Kalimantan Timur yang tentunya juga akan meningkatkan produksi kayu bulat nasional.

\section{Kata Kunci : Permenhut No.P.55/Menhut-II/2006, tata usaha kayu, efektif, efesien}

\section{PENDAHULUAN}

\section{A. Latar Belakang}

Permenhut No.P.55/Menhut-II/2006 adalah kebijakan penatausahaan hasil hutan yang berasal dari hutan negara yang berlaku saat ini. Kebijakan ini menggantikan SK Menteri Kehutanan No.126/KPTS-II/2003 yang dianggap kurang efektif karena menimbulkan biaya tinggi dan waktu yang cukup lama sehingga tidak mendorong pertumbuhan perekonomian pada sektor riil. Disamping itu SK Menteri Kehutanan No.126/KPTS-II/2003 tidak memberikan kepastian hukum karena masih mencampuradukkan antara hasil hutan yang menjadi aset negara dan aset privat milik perusahaan (Dirjen Bina Produksi Kehutanan, 2006).

Meski efektif diberlakukan sejak tanggal 1 Januari 2007, namun masih belum jelasnya pelaksanaan di lapangan dan ketidaksiapan sumberdaya manusia untuk menerbitkan dokumen sendiri menyebabkan pelaksanaan Permenhut No.P.55/Menhut-II/2006 di Kalimantan Timur baru dapat dilakukan sekitar bulan Maret 2007. Ketidaksiapan sumberdaya manusia sebagai penerbit dan kebingungan penerapan di lapangan akibat kondisi alam yang tidak ideal menjadi alasan sebagian besar perusahaan mengalami kesulitan untuk pelaksanaan Permenhut No.P.55/Menhut-II/2006 di lapangan. Kondisi ini bahkan sempat membuat sebagian perusahaan memilih untuk tidak berproduksi untuk sementara waktu (B2PD, 2007).

Di sisi lain, produksi kayu bulat Kalimantan Timur dari hutan alam merupakan penyumbang terbesar dari seluruh total produksi kayu bulat Indonesia dari hutan alam. Data dari Departemen Kehutanan (2007) menyebutkan bahwa pada tahun total produksi kayu bulat Indonesia asal hutan alam tahun 2006 adalah $5.586 .722 \mathrm{~m}^{3}$, di mana sekitar $1.987 .444 \mathrm{~m}^{3}$ berasal dari Kalimantan Timur. Sedangkan data dari sumber yang sama menyebutkan bahwa realisasi produksi kayu bulat Kalimantan Timur pada tahun 2006 sekitar 3.927.017 m³. Angka ini menunjukkan bahwa sekitar 50\% dari produksi kayu bulat Kalimantan Timur berasal dari hutan alam. Sebagian besar kayu bulat tersebut dipergunakan untuk memenuhi kebutuhan bahan baku industri pengolahan kayu 
di Kalimantan Timur. Data dari Departemen Kehutanan (2006) menyebutkan bahwa pada tahun 2005 di Kalimantan Timur ada sekitar 89 industri pengolahan kayu hulu yang masih beroperasi. Untuk memenuhi kebutuhan bahan baku industri tersebut Kalimantan Timur mendapat persetujuan Rencana Pemenuhan Bahan Baku Indutri (RPBBI) tahun 2005 sebesar 4.876.148,04 $\mathrm{m}^{3}$ dengan realisasi suplai bahan baku sebesar 3.762.476,08 $\mathrm{m}^{3}$. Jumlah ini berarti sekitar $28 \%$ dari total realisasi suplai bahan baku Indonesia pada tahun yang sama sebesar $13.308 .650,14 \mathrm{~m}^{3}$.

Melihat dari data-data tersebut di atas maka jelas bahwa perubahan kebijakan penatausahaan hasil hutan yang berasal dari hutan negara sangat berpengaruh terhadap industri pengolahan kayu Indonesia. Biaya tinggi dan waktu yang lama akibat ketidaksiapan pelaksanaan di lapangan dan ketidaksiapan sumberdaya manusia dalam pengurusan penatausahaan hasil hutan akan berpengaruh besar terhadap penurunan produksi kayu bulat Kalimantan Timur asal hutan alam yang berarti juga penurunan produktifitas industri pengolahan kayu Indonesia.

\section{B. Tujuan}

Tulisan ini dimaksudkan untuk menjelaskan tentang pelaksanaan Permenhut No.P.55/Menhut-II/2006 di Kalimantan Timur, permasalahan yang dihadapi dan dampaknya bagi suplai bahan baku industri kayu dari hutan alam, khususnya jenis dipterokarpa, di Kalimantan Timur.

\section{METODOLOGI PENELITIAN}

\section{A. Kerangka Pemikiran}

Kayu bulat asal hutan alam dari Kalimantan Timur, khususnya jenis dipterokarpa, memegang peranan cukup penting bagi industri pengolahan kayu di Indonesia. Karena sekitar 50\% dari total produksi kayu bulat Indonesia yang dipergunakan untuk bahan baku industri berasal dari Kalimantan Timur. Penggunaan kayu asal hutan alam masih sulit digantikan oleh kayu dari hutan tanaman atau hutan rakyat. Keunggulan kayu dari hutan alam, khususnya dari jenis dipterokarpa, seperti kekhasan dalam tekstur, sifat-sifat fisik kayu, tidak bergelombang, memiliki warna dan corak yang menarik menyebabkan hasil produk kayu olahannya bernilai tinggi dan sulit digantikan oleh kayu dari jenis lain.

Perubahan kebijakan penatausahaan hasil hutan kayu dari SK Menteri Kehutanan No.126/KPTS-II/2003 menjadi Permenhut No.P.55/Menhut-II/2006 diharapkan dapat memotong rantai birokrasi untuk menghemat waktu dan biaya. Tetapi jika Permenhut No.P.55/Menhut-II/2006 mengalami permasalahan dalam pelaksanaan di lapangan, ditambah lagi tidak mendapatkan jalan keluarnya, akan dapat berdampak negatif bagi industri pengolahan kayu Indonesia. Dan jika ini 
terjadi maka tujuan perubahan kebijakan penatausahaan memperpendek jalur birokrasi untuk menghemat waktu dan biaya tidak tercapai.

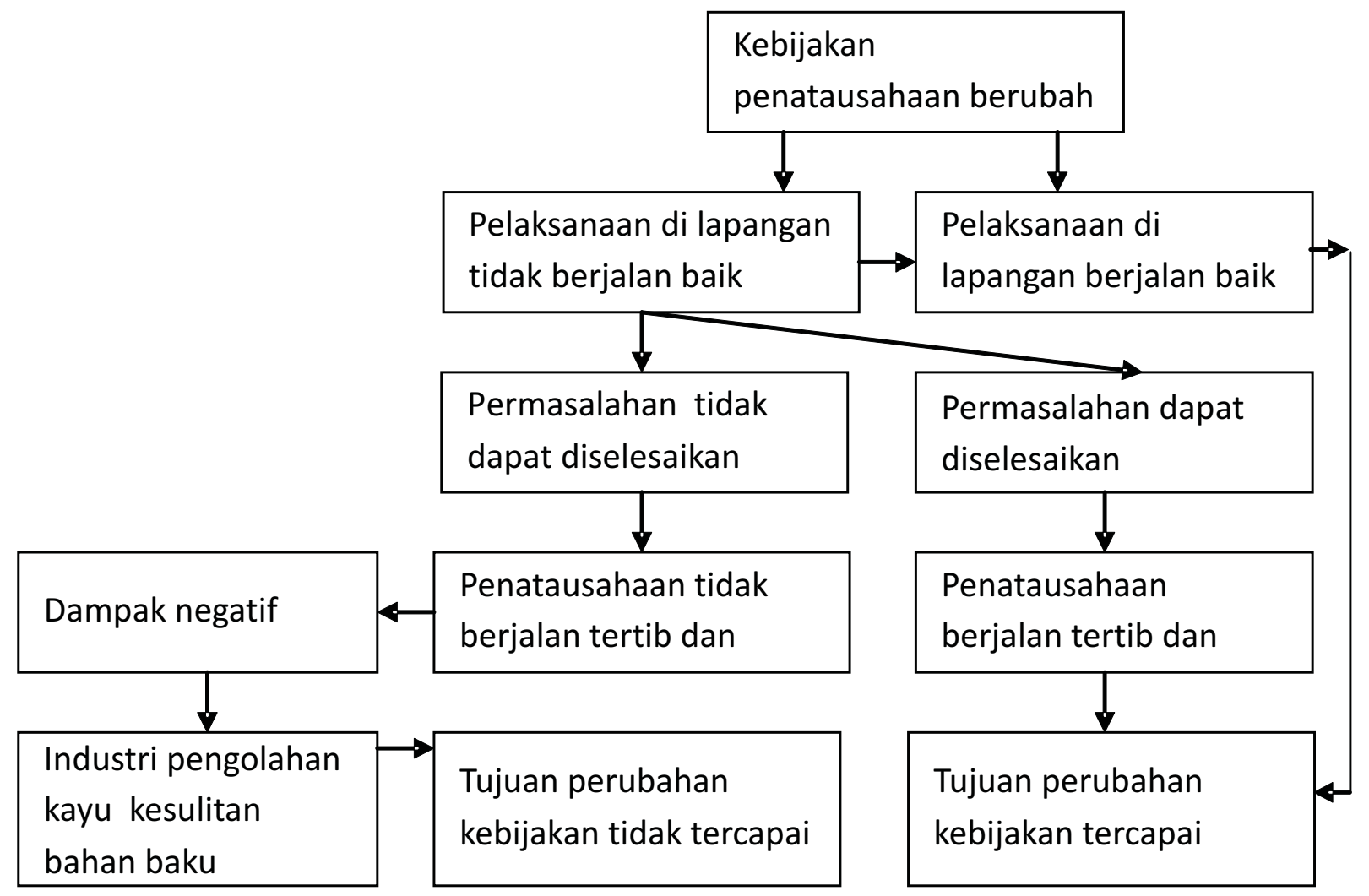

Gambar (Figure) 1. Kerangka Pemikiran Penelitian (Research Framework)

\section{B. Metode Pengumpulan Data}

Jenis data yang dikumpulkan dalam kegiatan ini adalah data primer dan data sekunder, dimana metode yang akan digunakan dalam pengumpulan data adalah dengan studi literatur, observasi dan wawancara dengan pihak-pihak terkait dalam kegiatan tata usaha kayu dipterokarpa. Pengumpulan data dilakukan secara purposive sampling terhadap 40 responden yang mewakili pola sistem tata usaha pengusahaan kayu dipterokarpa baik yang berasal dari hutan alam maupun hutan tanaman, diantaranya dari PT Balikpapan Forest Industries dan PT. Sumalindo Lestari Jaya, Tbk yang mewakili IUPHHK (HPH), PT. Inne Dong Hwa dan PT. Melapi Timber yang mewakili IPKH (industri), Dinas Kehutanan Propinsi Kalimantan Timur, Dinas Kehutanan Kabupaten Kutai Kertanegara, Dinas Kehutanan Kabupaten Kutai Barat, Dinas Kehutanan Kabupaten Penajam Paser Utara, UPTD Peredaran Hasil Hutan (PHH) Mahakam Hilir Samarinda, UPTD PHH Balikpapan, dan Asosiasi Pengusaha Hutan Indonesia (APHI). 


\section{Metode Analisis Data}

Metode analisis data menggunakan analisis keefektifitasan dan keefisiensian sistem tata usaha kayu dipterokarpa. Untuk analisis sistem tata usaha kayu akan dilakukan dengan cara deskripsi kualitatif, dimana efektifitas dari tata usaha kayu yang sedang berjalan akan dilakukan dengan mengkaji sejauh mana pelaku tata usaha memenuhi fungsinya dan bagaimana pelaksanaan mekanisme check and balance. Sedangkan untuk mengetahui efisiensi dari tata usaha kayu yang sedang berjalan akan dilakukan dengan mengkaji faktor yang mempengaruhi waktu dan biaya yang diperlukan setiap pelaku tata usaha dalam pemenuhan fungsinya.

\section{HASIL DAN PEMBAHASAN}

\section{A. Kebijakan Penatausahaan Hasil Hutan Kayu dari Hutan Alam}

Penatausahaan hasil hutan adalah kegiatan yang meliputi penatausahaan tentang perencanaan produksi, pemanenan atau penebangan, penandaan, pengukuran dan pengujian, pengangkutan/peredaran dan penimbunan, pengolahan dan pelaporan. Penatausahaan hasil hutan dimaksudkan untuk memberikan kepastian hukum dan pedoman kepada semua pihak yang melakukan usaha atau kegiatan di bidang kehutanan, sehingga penatausahaan dapat berjalan dengan tertib dan lancar, agar kelestarian hutan, pendapatan negara, dan pemanfataan hasil hutan dapat secara optimal dapat tercapai. Dengan kata lain jika penatausahaan hasil hutan dapat berjalan dengan tertib dan lancar maka hutan tetap lestari dan pemerintah mendapatkan pembiayaan pembangunan. Perubahan kebijakan penatausahaan Permenhut No.P.55/Menhhut-II/2006 dari SK Menhut 126/KPTS-II/2003 dimaksudkan untuk :

a. Menyederhanakan/menderegulasi sistem penatausahaan hasil hutan yang lama;

b. Fokus pada pengamanan aset negara (kayu bulat dari hutan alam negara sebagai bahan baku industri), dan;

c. Tidak mencampuradukkan aset negara dengan aset privat dan sekaligus memberikan kepastian hukum terhadap hasil hutan yang telah menjadi aset/milik perusahaan/perorangan (Dirjen Bina Produksi Kehutanan, 2006).

Adapun yang menjadi dasar pemikiran perubahan kebijakan penatausahaan hasil hutan dari SK Menhut 126/KPTS-II/2003 menjadi Permenhut No.P.55/Menhut-II/2006, disebabkan karena penatausahaan yang lama bersifat official assesment dan pelaksanaannya sangat dipengaruhi oleh otonomi daerah. Dilatarbelakangi oleh kepentingan dan kebutuhan masing-masing daerah maupun kepentingan pejabat yang berwenang di daerah tersebut menyebabkan pelaksanaan sistem penatausahaan yang sangat bervariasi di masing-masing daerah. Kondisi ini menyebabkan pelaksanaan penatausahaan kayu menjadi tidak efektif dari segi waktu dan biaya dan dapat berdampak pada high cost economy (biaya pengurusan yang tinggi). Salah satu contoh kasus terjadi 
di Kalimantan Timur dimana untuk pengurusan penerbitan dokumen Surat Keterangan Sahnya Hasil Hutan (SKSHH) harus melewati kurang lebih 20 (dua puluh) meja (Syahadat, 2006). Tentu saja hal tersebut sangat membebani pihak perusahaan karena tidak efektif dari segi waktu maupun tidak efisien dari segi biaya karena terlalu banyaknya pelaku yang terlibat.

Secara garis besar perbedaan pelaksanaan Permenhut No.P.55/Menhut-II/2006 dari SK Menhut 126/KPTS-II/2003 adalah:

1. Mendefinisikan kembali surat keterangan sahnya hasil hutan (skshh) sebagai "general term" dan bukan nama dokumen. Dalam hal ini surat keterangan sahnya hasil hutan dapat berupa semua dokumen yang menyatakan bahwa hasil hutan tersebut sah pada setiap segmen kegiatan seperti Laporan Hasil Cruising (LHC), Rencana Karya Tahunan (RKT), Laporan Hasil Penebangan (LHP), Surat Keterangan Sah Kayu Bulat (SKSKB), Faktur Angkutan Kayu Bulat (FAKB) dan lain-lain.

2. Memberlakukan dokumen SKSKB untuk pengangkutan kayu bulat dari hutan alam sampai tempat tujuan atau industri, dokumen FAKB untuk kayu yang berasal dari hutan tanaman, dokumen Faktur Angkutan Kayu Olahan (FA-KO) untuk semua hasil hutan yang keluar dari industri atau berbentuk kayu olahan, dan dokumen FA-KB sebagai pengganti dokumen SKSKB lanjutan.

3. Pengadaan blangko dan penerbitan dokumen SKSKB dilakukan oleh aparat Pemerintah, termasuk pengadaan blankonya, sedangkan pengadaan blanko dan penerbitan dokumen faktur oleh perusahaan pemilik kayu. Khusus bagi IUPHHK yang dinilai baik dalam mengelola hutan akan mendapatkan insentif, yaitu penerbitan SKSKB dapat dilakukan secara mandiri.

4. Untuk mempermudah pengendalian dan keseragaman, format blanko faktur ditetapkan Dephut, dengan pengaturan warna sebagai berikut : (a) Propinsi di Jawa, Madura, Bali, NTB dan NTT menggunakan blanko warna putih; (b) Propinsi di Sumatera menggunakan warna blanko kuning; (c) Provinsi di Kalimantan menggunakan warna blanko merah; (d) Propinsi di Sulawesi menggunakan warna blanko biru; (e) Propinsi di Maluku, Irian Jaya Barat dan Papua menggunakan warna blanko hijau.

\section{B. Gambar Umum dan Potensi Hutan Alam di Kalimantan Timur}

Dari hasil paduserasi Rencana Tata Ruang Wilayah (RTRW) dan Tata Guna Hutan Kesepakatan (TGHK) Kalimantan Timur yang ditetapkan Gubernur Kaltim melalui Nomor 050/K443/1999 tanggal 01 September 1999 diketahui bahwa dari luas total daratan $200.395 \mathrm{~km}^{2}$ masih tersisa kawasan budidaya kehutanan seluas $97.113 \mathrm{~km}^{2}$ dan kawasan lindung seluas $49.169 \mathrm{~km}^{2}$. Sedangkan Keputusan Menteri Kehutanan nomor 79/Kpts-II/2001 tanggal 15 Maret 2001 tentang Penunjukan Kawasan Hutan dan perairan di wilayah Provinsi Kalimantan Timur menyebutkan luasannya sekitar 14.651.553 Ha yang terdiri dari : 
a. Kawasan Konservasi

- Hutan Cagar Alam

- Hutan Taman Nasional

- Hutan Wisata Alam

b. Hutan Lindung

c. Hutan Produksi Terbatas

d. Hutan Produksi Tetap
173.272 Ha.

$1.930 .076 \mathrm{Ha}$.

$61.850 \mathrm{Ha}$.

$2.751 .702 \mathrm{Ha}$.

4.612.965 Ha.

$5.121 .688 \mathrm{Ha}$.

Dalam kurun waktu 10 tahun terakhir, produksi kayu bulat Kalimantan Timur mengalami turun naik. Pada tahun 1997 produksi kayu bulat Kalimantan Timur pernah mencapai $6.600 .654 \mathrm{~m}^{3}$, tetapi pada tahun 2001 produksi kayu bulat Kalimantan Timur hanya mencapai $970.054 \mathrm{~m}^{3}$. Belakangan jumlah ini terus mengalami peningkatan hingga pada tahun 2006 mencapai 3.927.017 $\mathrm{m}^{3}$. Meski angka ini agak berbeda dengan data dari Dinas Kehutanan Kalimantan Timur (2008), tetapi sekitar 11\% - 27\% total produksi kayu bulat Indonesia berasal dari Kalimantan Timur.

Tabel (Table) 1. Perbandingan Produksi Kayu Bulat Kaltim dengan Produksi Nasional dalam 4 (Empat) Tahun Terakhir (Comparison of Logs Production in East Kalimantan with the National Production in the last 4 (Four) Years)

\begin{tabular}{|c|c|c|c|c|c|c|c|}
\hline \multirow[t]{2}{*}{$\begin{array}{l}\text { No. } \\
\text { (Num } \\
\text { ber) }\end{array}$} & \multirow[t]{2}{*}{$\begin{array}{l}\text { Tahun } \\
\text { (Year) }\end{array}$} & \multirow{2}{*}{$\begin{array}{c}\text { Jatah } \\
\text { Tebang }\left(\mathrm{m}^{3}\right) \\
\begin{array}{c}\text { Allowable } \\
\text { Cut })\end{array} \\
\end{array}$} & \multicolumn{2}{|c|}{$\begin{array}{c}\text { Departemen } \\
\text { Kehutanan } \\
\text { (Ministry of Forestry) }\end{array}$} & \multicolumn{2}{|c|}{$\begin{array}{c}\text { Dinas Kehutanan } \\
\text { Kaltim } \\
\text { (East Kalimantan } \\
\text { Forest Service) }\end{array}$} & \multirow[t]{2}{*}{$\begin{array}{c}\text { Total produksi kayu } \\
\text { bulat Nasional }\left(\mathrm{m}^{3}\right) \\
\text { (Total National } \\
\text { Production of logs) }\end{array}$} \\
\hline & & & $\left(\mathrm{m}^{3}\right)$ & $\%$ & $\left(\mathrm{~m}^{3}\right)$ & $\%$ & \\
\hline 1. & 2003 & & 1.721 .605 & 15 & $2.895 .896,49$ & 25 & 11.423 .501 \\
\hline 2. & 2004 & 1.555 .000 & 2.150 .259 & 16 & $3.726 .541,24$ & 27 & 13.548 .938 \\
\hline 3. & 2005 & 1.531 .023 & 3.538 .880 & 15 & $3.587 .585,49$ & 15 & 24.222 .638 \\
\hline 4. & 2006 & 2.582 .230 & 3.927 .017 & 18 & $2.373 .034,54$ & 11 & 21.792 .144 \\
\hline
\end{tabular}

Sumber: Departemen Kehutanan (2006), Departemen Kehutanan (2007) dan Dinas Kehutanan Kaltim (2008)

Dilihat dari sumbernya, kayu bulat Kalimantan Timur sebagian besar diperoleh dari hutan alam yaitu dari Rencana Karya Tahunan (RKT) dan Izin Pemanfaatan Kayu (IPK), hanya sedikit yang berasal dari Hutan Tanaman Industri (HTI). Bila dilihat dari persentasenya maka kayu bulat Kalimatan Timur asal hutan alam memberikan kontribusi cukup besar, yaitu sekitar 40\%, kepada produksi kayu bulat nasional. 
Tabel (Table) 2. Perbandingan Produksi Kayu Bulat Kalimantan Timur dengan Produksi Nasional Berdasarkan Sumber Produksi Tahun 2006 (Comparison of Production of Logs in East Kalimantan with the National Production based from Production Source in 2006)

\begin{tabular}{|l|l|c|c|c|}
\hline $\begin{array}{c}\text { No. } \\
\text { (Num } \\
\text { ber })\end{array}$ & \multicolumn{1}{|c|}{$\begin{array}{c}\text { Tahun } \\
\text { (Year) }\end{array}$} & \multicolumn{2}{|c|}{$\begin{array}{c}\text { Kalimantan Timur } \\
\text { (East Kalimantan) }\end{array}$} & $\begin{array}{c}\text { Nasional } \\
\text { (National) }\end{array}$ \\
\cline { 2 - 5 } & $\left.\mathbf{( m}^{\mathbf{3}}\right)$ & $\mathbf{\%}$ & $\left.\mathbf{( m}^{\mathbf{3}}\right)$ \\
\hline 1. & RKT & 1.987 .444 & 0.36 & 5.586 .722 \\
\hline 2. & IPK & 1.404 .269 & 0.41 & 3.434 .181 \\
\hline 3. & HTI & 535.305 & 0.05 & 11.451 .249 \\
\hline & Jumlah & $\mathbf{3 . 9 2 7 . 0 1 7}$ & $\mathbf{0 . 1 8}$ & $\mathbf{2 1 . 7 9 2 . 1 4 4}$ \\
\hline
\end{tabular}

Sebagian besar kayu bulat Kalimantan Timur dipergunakan untuk memenuhi kebutuhan bahan baku industri pengolahan kayu sendiri. Secara umum industri pengolahan kayu terbagi atas Industri Pengolahan Kayu Hulu (IPKH) yang berbahan baku kayu bulat seperti industri kayu lapis dan kayu gergajian, dan Industri Pengolahan Kayu Lanjutan (IPKL) yang menggunakan kayu gergajian sebagai bahan baku. Data terakhir menyebutkan bahwa sampai tahun 2005 di Kalimantan Timur ada sekitar 89 unit industri pengolahan kayu yang masih beroperasi, dimana 86 unit adalah IPKH dan sisanya 3 unit adalah IPKL (Departemen Kehutanan, 2006).

Tabel (Table) 3. Rekapitulasi Kapasitas Izin Industri Pengolahan Kayu di Kalimantan Timur Tahun 2005 (Recapitulation of Wood Processing Industries in East Kalimantan in 2005)

\begin{tabular}{|c|c|c|c|c|c|}
\hline \multirow{2}{*}{$\begin{array}{l}\text { No. } \\
\text { (Num } \\
\text { ber })\end{array}$} & \multirow{2}{*}{$\begin{array}{c}\text { Jenis Kayu Olahan } \\
\text { (Various Form of Wood } \\
\text { Processing Product) }\end{array}$} & \multicolumn{2}{|r|}{$>6.000$} & \multicolumn{2}{|r|}{$\geq 6.000$} \\
\hline & & $\begin{array}{l}\text { Unit } \\
\text { (Unit) }\end{array}$ & $\begin{array}{c}\text { Kapasitas }\left(\mathbf{m}^{3} / \text { tahun }\right) \\
(\text { Capasity) }\end{array}$ & $\begin{array}{c}\text { Unit } \\
\text { (Unit) }\end{array}$ & $\begin{array}{c}\text { Kapasitas }\left(\mathrm{m}^{3} / \text { tahun }\right) \\
\text { (Capasity) }\end{array}$ \\
\hline 1. & Kayu Gergajian & 41 & 1.145 .080 & 24 & 83.400 \\
\hline 2. & Kayu Lapis & 21 & 2.109 .633 & & \\
\hline 3. & Chip & 1 & 235.700 & & \\
\hline 4. & Pulp & 1 & 525.000 & & \\
\hline 5. & MDF & 1 & 200.000 & & \\
\hline
\end{tabular}

Sumber: Departemen Kehutanan (2006) 
Tabel (Table) 4. Perkembangan Produksi Kayu Olahan di Kalimantan Timur dalam 5 (Lima) Tahun Terakhir (Timber Production Progress in East Kalimantan in the last 5 (five) years)

\begin{tabular}{|c|c|c|c|c|c|c|}
\hline \multirow{2}{*}{$\begin{array}{l}\text { No. } \\
\text { (Num } \\
\text { ber) }\end{array}$} & \multirow{2}{*}{$\begin{array}{l}\text { Jenis Kayu Olahan } \\
\text { (Various Form of Wood } \\
\text { Processing Product) }\end{array}$} & \multicolumn{5}{|c|}{ Tahun $\left(\mathrm{m}^{3}\right)$ (Year) } \\
\hline & & 2002 & 2003 & 2004 & 2005 & 2006 \\
\hline 1. & Kayu Gergajian & 206.097 & 198.279 & 20.193 & 276.668 & 111.151 \\
\hline 2. & Kayu Lapis & 80.622 & 1.600 .745 & 858.153 & 927.960 & 476.206 \\
\hline 3. & Wood Working & - & - & 225.316 & 16.133 & 4.994 \\
\hline 4. & Veneer & - & 155.254 & - & 200.904 & 4.365 \\
\hline 5. & Block Board & 68.696 & 118.162 & 44.783 & 76.145 & 42.255 \\
\hline 6. & Moulding & 52.259 & 52.345 & 54.002 & 47.970 & 19.840 \\
\hline 7. & Pulp & - & 539.698 & 164.745 & - & 65.669 \\
\hline 8. & Chipwood & - & - & 147.220 & 281.010 & 659.220 \\
\hline
\end{tabular}

Sumber : Departemen Kehutanan (2007)

\section{Keefektifitasan dan Keefesiensian Tata Usaha Kayu di Kalimantan Timur}

Pelaksanaan tata usaha kayu yang efektif dan efesien dapat berdampak terhadap keberlangsungan industri perkayuan khususnya di Kalimantan Timur. Hal ini dapat diketahui melalui kinerja dari pelaku tata usaha dalam memenuhi peran dan fungsinya serta bagaimana pelaksanaan mekanisme check and balance dari para pelaku yang terkait. Data keefektifitasan tata usaha kayu disajikan pada Tabel 5 berikut : 


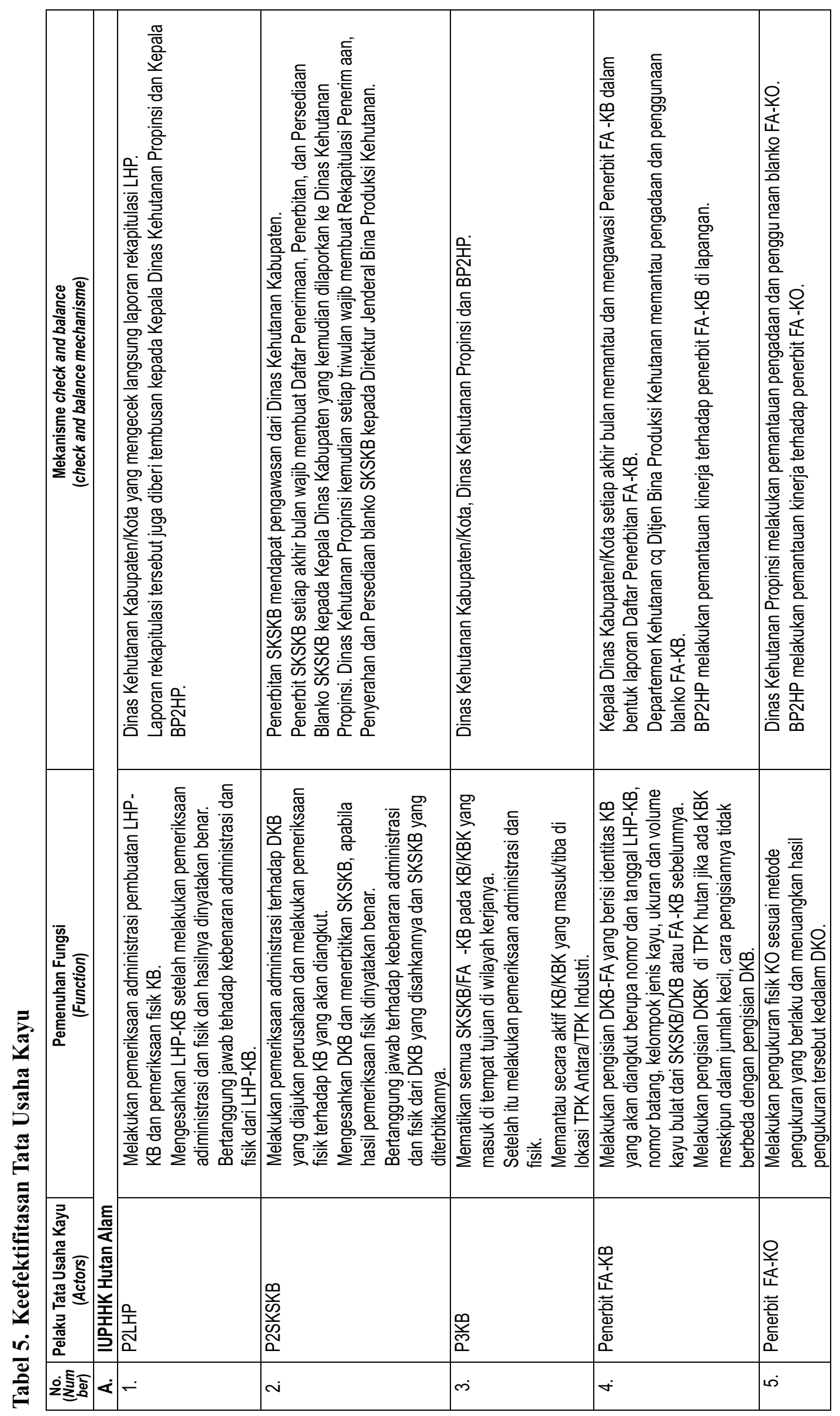




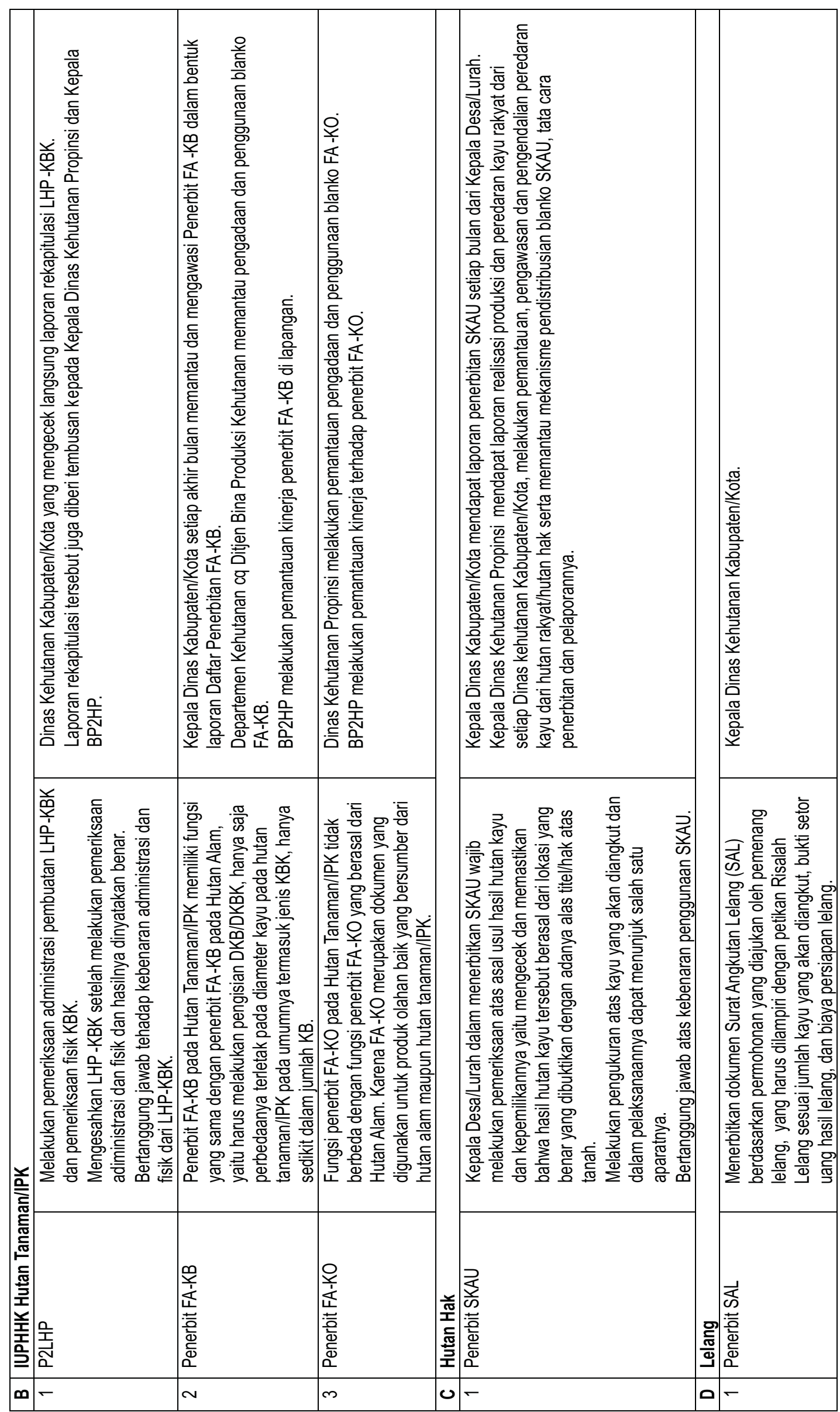


Dari hasil analisis keefektifitasan tata usaha kayu diketahui bahwa masing-masing pelaku tata usaha sudah melaksanakan fungsi dan mekanisme check dan balance secara benar sesuai aturan kebijakan penatausahaan kayu yang dikeluarkan Departemen Kehutanan. Hanya saja beberapa kasus didapati bahwa Dinas Kehutanan Propinsi tidak menerima laporan penggunaan dokumen (SKSKB/FA-KB/FA-KO) dari beberapa Dinas Kabupaten/Kota di Kalimantan Timur. Hal ini sangat mungkin terkait dengan tarik ulur kewenangan propinsi dengan kabupaten akibat otonomi daerah.

Sedangkan untuk mengetahui keefisiensian dari tata usaha kayu, parameter yang digunakan adalah waktu dan biaya yang dibutuhkan dalam setiap pemenuhan fungsi. Data keefesiensian tata usaha kayu disajikan pada Tabel 6 berikut : 


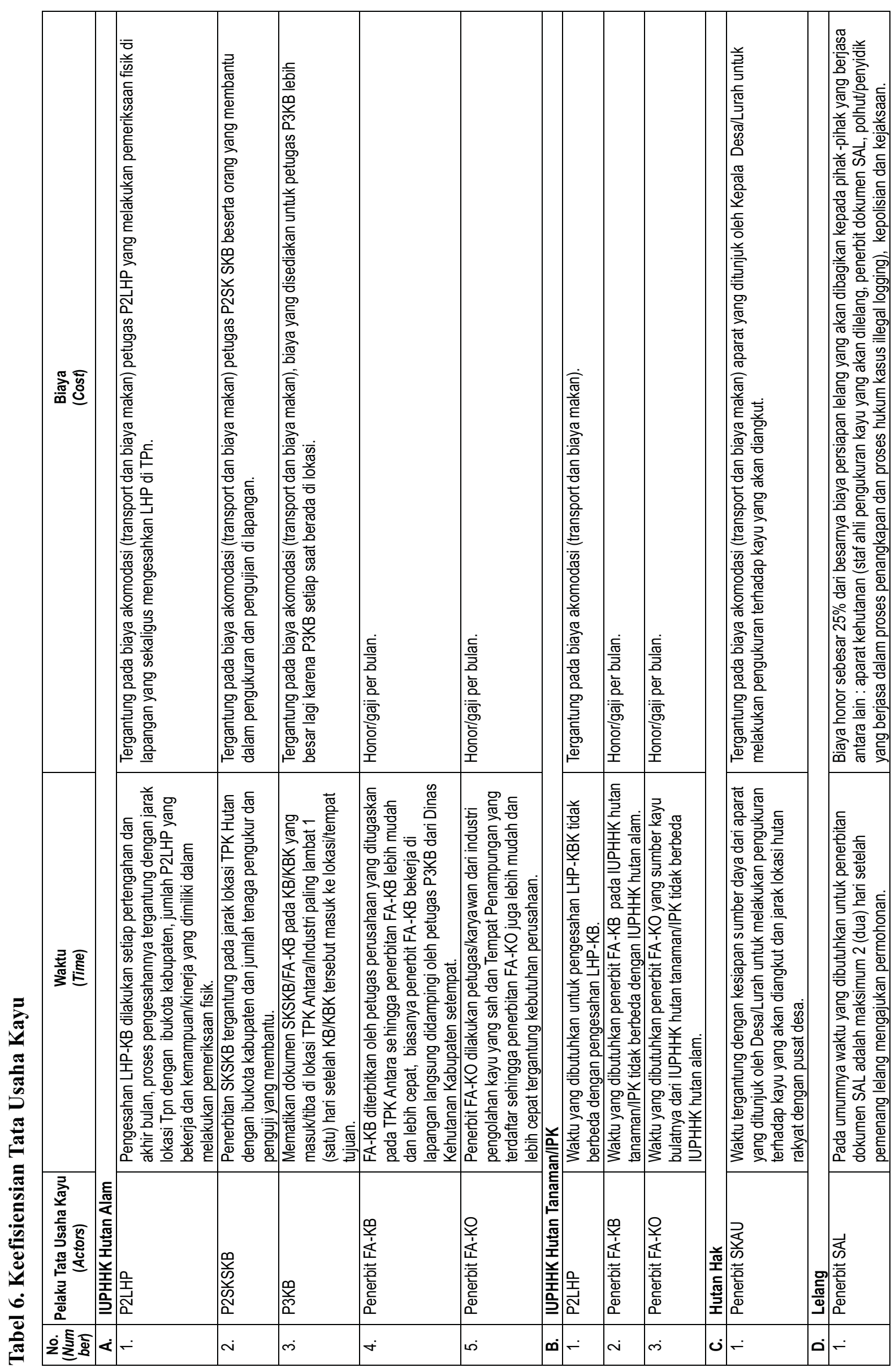


Dari hasil analisis keefisiensian tata usaha kayu diketahui bahwa lamanya waktu pelaku tata usaha kayu dalam memenuhi fungsinya tergantung pada lokasi/jarak tempuh dari areal kerja dengan ibukota kabupaten dan jumlah tenaga kerja yang membantu. Sedangkan besarnya biaya yang diperlukan tergantung pada biaya akomodasi (transport dan biaya makan). Biaya ini biasanya dibebankan kepada perusahaan yang memerlukan pejabat penerbit/pengesah/pengawas/pemeriksa dokumen. Tidak ada standar baku besarnya biaya, karena tergantung faktor kondisi alam dan petugas yang menjalankan tugas.

\section{Permasalahan dalam Pelaksanaan Kebijakan Pengangkutan Hasil Hutan Kayu dari Hutan Alam dan Dampaknya terhadap Potensi Hutan Alam}

Dari hasil penelitian diperoleh informasi bahwa pada awal pelaksanaan Permenhut No. P.55/Menhut-II/2006 secara umum sebagian besar perusahaan kayu di Kalimantan Timur mengalami 2 (dua) permasalahan, yaitu masalah ketersediaan sumber daya manusia sebagai pejabat Pejabat Pemeriksa dan Penerimaan Kayu Bulat (P3KN) dan petugas penerbit dokumen FAKB dan FAKO serta masalah substansi Permenhut No. P.55/Menhut-II/2006.

Secara rinci permasalahan dalam pelaksanaan Permenhut No. P.55/Menhut-II/2006 di Kalimantan Timur adalah sebagai berikut:

1. Ketidak jelasan substansi Permenhut No. P.55/Menhut-II/2006

a. Istilah TPK Hutan dipergunakan dalam Permenhut No. P.55/Menhut-II/2006, padahal pasal 1 hanya mencantumkan pengertian TPn (ayat 20), TPK (ayat 21) dan TPK Antara (ayat 23). Permasalahan ini dapat menimbulkan salah tafsir pelaksanaan di lapangan.

b. Permenhut No. P.55/Menhut-II/2006 pasal 1 menyebutkan bahwa Tempat Penimbunan Kayu (TPK) adalah tempat milik pemegang IUPHHK/IPHHK/IPK di dalam atau di sekitar arealnya yang berfungsi menimbun kayu bulat dan atau kayu bulat kecil dari TPn. Tetapi tidak adanya penjelasan berapa jarak maksimal TPK dari areal izinnya menyebabkan perbedaan persepsi tentang jarak yang diperkenankan.

c. Istilah Nota Perusahaan dipergunakan dalam Permenhut No. P.55/Menhut-II/2006, tetapi tidak mencantumkan definisi dan contoh blangko sehingga dapat menimbulkan perbedaan persepsi dan juga persoalan hukum dengan pihak luar instansi kehutanan.

\section{Ketidaksinkronan dengan kebijakan lain}

a. Permenhut No. P.55/Menhut-II/2006 pasal 10 menyebutkan bahwa LHP yang telah disahkan dijadikan dasar penghitungan pembayaran PSDH dan DR, padahal Permenhut No. P.79/Menhut-II/2006 dan Permenhut No. P.80/Menhut-II/2006 menyebutkan bahwa pembayaran PSDH dan DR berdasarkan Usulan LHP.

b. Permenhut No. P.55/Menhut-II/2006 pasal 9 menyebutkan bahwa pengangkatan petugas pembuat LHP harus mendapatkan rekomendasi teknis dari Kepala Balai, padahal setiap 
petugas sudah diwajibkan memiliki Sertifikat dan Kartu Penguji (KP) dari Kepala Balai.

c. Permenhut No. P.55/Menhut-II/2006 tidak mengharuskan adanya dokumen angkut sepanjang berada di dalam areal konsesi, sedangkan PP No. 6 Tahun 2007 dan UU No. 41 Tahun 199 mewajibkan setiap pengakutan hasil hutan yang berasal dari hutan negara harus disertai dokumen.

\section{Ketidakefisiensian dalam pelaksanaan}

a. Permenhut No. P.55/Menhut-II/2006 pasal 10 menyebutkan bahwa pengesahan LHP-KB dilaksanakan oleh P2LHP di TPn, padahal umumnya lokasi TPn di IUPHHK Hutan Alam dan IUPHHK Hutan Tanaman lokasinya terpencar.

b. Permenhut No. P.55/Menhut-II/2006 pasal 19 menyebutkan bahwa penetapan TPK Antara hanya berlaku untuk jangka waktu 1 (satu) tahun sedangkan penetapan TPK Antara juga memerlukan izin dari Dinas Perhubungan dan Syah Bandar yang mempunyai jangka waktu 3 - 5 tahun. Perbedaan masa berlaku dan penafsiran yang umum berlaku bahwa 1 (satu) tahun berarti hanya sampai 31 Desember tahun berjalan, membuat perusahaan setiap tahun harus memperpanjang izin yang membutuhkan waktu, tenaga dan biaya yang tidak sedikit.

c. Permenhut No. P.55/Menhut-II/2006 pasal 13 ayat (3) menyebutkan bahwa setiap pengangkutan KB dari TPK Hutan dalam areal IUPHHK/IPK dengan tujuan lain di luar areal izin wajib disertai bersama-sama dengan dokumen SKSKB dan Permenhut No. P.55/Menhut-II/2006 pasal 14 ayat (1) menyebutkan bahwa penggunaan dokumen SKSKB, FAKB, FAKO dan FAHHBK hanya berlaku untuk 1 (satu) kali penggunaan, 1 (satu) pemilik, 1 (satu) jenis komoditas hasil hutan, 1 (satu) alat angkut dan 1 (satu) tujuan pengangkutan. Aturan ini menyebabkan dokumen SKSKB yang diperlukan perusahaan menjadi sangat banyak. Sebagai gambaran untuk memuat kayu bulat sebanyak $1.700 \mathrm{~m}^{3}$ dibutuhkan 124 set dokumen SKSKB. Banyaknya dokumen SKSKB yang diperlukan membuat waktu penyelesaian menjadi lama mengingat petugas penerbit harus mengambil blangko dokumen SKSKB ke Dinas Kehutanan Kabupaten yang jaraknya jauh dan proses pengambilan memerlukan persyaratan administrasi yang cukup detil karena harus dilengkapi Daftar Kayu Bulat (DKB) serta dibuatkan Berita Acara Pemeriksaan (BAP) (pasal 17 dan 18). Aturan ini sangat memberatkan terutama jika kondisi petak tebangan jauh dari logpond dan cuaca tidak mendukung.

d. Batasan penggunanaan dokumen pada Permenhut No. P.55/Menhut-II/2006 pasal 14 ayat (1) juga membuat penerbitan FAKB sangat tidak efisien bagi pengusahaan hutan tanaman. Dengan daya angkut $\pm 8 \mathrm{~m}^{3}$ per truk, maka jika dalam 1 (satu) hari misalnya akan mengeluarkan kayu sebanyak $2.000 \mathrm{~m}^{3}$, maka perusahaan harus menerbitkan 250 dokumen FAKB per hari.

e. Permenhut No. P.55/Menhut-II/2006 pasal 6 menyebutkan bahwa penandaan pada batang 
berupa pemberian nomor batang, nomor petak tebangan, diameter rata-rata, panjang dan jenis kayu, pada kayu hutan rawa dilakukan pada badan kayu. Ini sangat tidak efektif karena akan menyulitkan saat identifikasi apabila kayu sudah ditumpuk di TPn dan saat sudah dimuat ke dalam truck atau ponton.

\section{KESIMPULAN DAN SARAN}

\section{A. Kesimpulan}

Beberapa kesimpulan dari penelitian ini adalah sebagai berikut :

1. Dari hasil analisis keefektifitasan tata usaha kayu yang mengacu pada Permenhut No.P.55/Menhut-II/2006 di Kalimantan Timur diketahui bahwa masing-masing pelaku tata usaha sudah melaksanakan fungsi dan mekanisme check dan balance sesuai aturan kebijakan. Hanya saja terkait dengan tarik ulur kewenangan propinsi dengan kabupaten akibat otonomi daerah, beberapa kasus didapati bahwa Dinas Kehutanan Propinsi tidak menerima laporan penggunaan dokumen (SKSKB/FA-KB/FA-KO) dari beberapa Dinas Kabupaten/Kota di Kalimantan Timur.

2. Dari hasil analisis keefesiensian perubahan kebijakan penatausahaan hasil hutan kayu dari SK Menhut 126/KPTS-II/2003 menjadi Permenhut No.P.55/Menhut-II/2006 menyebabkan beberapa perusahaan di Kalimantan Timur mengeluarkan biaya tinggi dan waktu yang lama, karena lokasi areal kerja perusahaan yang cukup jauh dari ibukota kabupaten.

3. Permasalahan utama yang dihadapi di Kalimantan Timur terkait perubahan kebijakan penatausahaan hasil hutan adalah ketidaksiapan sumberdaya manusia, yaitu ketersediaan Pejabat Pemeriksa dan Penerimaa Kayu Bulat (P3KN) dan petugas penerbit dokumen FAKB dan FAKO. Sedangkan masalah lain yang dihadapi adalah masalah substansi Permenhut P.55/Menhut-II/2006, diantaranya ketidakjelasan substansi, ketidaksinkronan dengan kebijakan lain dan ketidakefisiensian dalam pelaksanaan di lapangan akibat kondisi alam yang tidak ideal.

4. Pelaksanaan Permenhut P.55/Menhut-II/2006 yang belum efektif dan efisien jelas berdampak terhadap industri pengolahan kayu di Indonesia. Ketidakefektifan dan ketidakefisiensian tersebut sempat membuat beberapa perusahaan di Kalimantan Timur memilih untuk tidak berproduksi sementara waktu, padahal kayu bulat Kalimantan Timur dari hutan alam merupakan pasokan terbesar bahan baku industri Kalimantan Timur yang menyumbang sekitar 28\% suplai bahan baku industri Indonesia. 


\section{B. Saran}

Mekanisme check dan balance dari pelaksanaan tata usaha kayu yang disampaikan dalam penelitian ini hanya bersifat umum. Mekanisme check dan balance dari pelaksanaan tata usaha kayu sangat bergantung dari kebijakan internal dari masing-masing Dinas Kehutanan Kabupaten/Kota. Karena penelitian ini hanya dilakukan pada beberapa Kabupaten/Kota di Kalimantan Timur, maka diperlukan penelitian lanjutan jika ingin mengetahui mekanisme check dan balance secara menyeluruh dari pelaksanaan tata usaha kayu di Kalimantan Timur.

\section{DAFTAR PUSTAKA}

Balai Besar Penelitian Dipterokarpa, 2007. Kajian Tata Usaha dan Tata Niaga Kayu Dipterokarpa. Laporan Tahunan Kegiatan Penelitian (tidak dipublikasikan). Samarinda.

Bidang Statistik Kehutanan, 2006. Eksekutif, Data Strategis Kehutanan 2006. Pusat Rencana dan Statistik Kehutanan. Badan Planologi Kehutanan. Departemen Kehutanan.

Bidang Statistik Kehutanan, 2007. Statistik Kehutanan Indonesia 2006. Pusat Rencana dan Statistik Kehutanan. Badan Planologi Kehutanan. Departemen Kehutanan.

Keputusan Menteri Kehutanan No. 126/Kpts-II/2003, tanggal 4 April 2003 Tentang Penatausahaan Hasil Hutan. Departemen Kehutanan. Jakarta

Syahadat, E. 2006. Kajian Mekanisme Permohonan Penerbitan Surat Keterangan Sahnya Hasil Hutan (SKSHH) (Kasus di Propinsi Kalimantan Timur). Diakses dari www.puslitsosekbud.web.id tanggal 20 September 2010.

Peraturan Menteri Kehutanan No. P.55/Menhut-II/2006, Tanggal 29 Agustus 2006 Tentang Penatausahaan Hasil Hutan Yang Berasal Dari Hutan Negara. Departemen Kehutanan. Jakarta.

Pranowo, B. 2008. Kondisi Hutan dan Perhutanan Sosial di Kalimantan Timur. Makalah dalam Sosialisasi Permenhut P.37/Menhut-II/2007 tentang Hutan Kemasyarakatan (HKm), 27 April 2008. Samarinda.

Widyantoro, B dan Dody Sukadri. 2007. Peluang Pasar Produk Hutan Tanaman Dipterokarpa. Makalah dalam Seminar Pengembangan Hutan Tanaman Dipterokarpa dan Ekspose TPTII/SILINT. Balai Besar Penelitian Dipterokarpa, 4 - 5 September 2007. Samarinda. 
Yuniati, D. 2004. Kajian Penyediaan dan Permintaan Kayu Bulat untuk Kebutuhan Industri Pengolahan Kayu di Kalimantan Timur. Dipterokarpa, Visi dan Misi Teknis Balai Penelitian dan Pengembangan Kehutanan Kalimantan. Vol. 8 No. 1, 2004. Samarinda. 